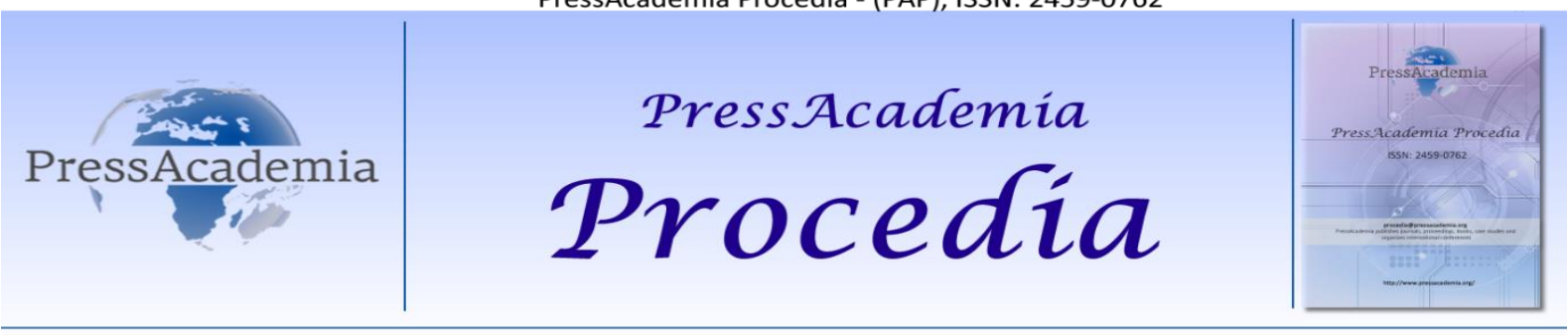

Global Business Research Congress (GBRC), May 24-25, 2017, Istanbul, Turkey.

\title{
EFFECTS OF PROCEDURAL JUSTICE ON EMPLOYEES' JOB SATISFACTION AND NEW IDENTIFICATION AFTER MERGER AND NEW IDENTIFICATION'S MEDIATING ROLE IN THIS RELATIONSHIP.
}

\author{
DOI: 10.17261/Pressacademia.2017.677 \\ PAP- GBRC-V.3-2017(104)-p.952-971 \\ Yurdagul Meral ${ }^{1}$, Murat Yaslioglu ${ }^{2}$

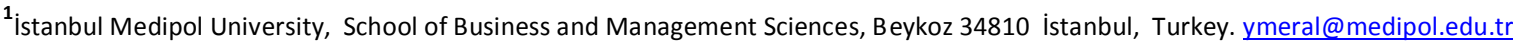 \\ ${ }^{2}$ istanbul University, School of Business, Avcılar Kampüsü 34322 Avcılar, İstanbul, Turkey. muratyas@istanbul.edu.tr
}

\section{To cite this document}

Meral, Y. and M.Yaslioglu, (2017). Effects of procedural justice on employees' job satisfaction and new identification after merger and new identification's mediating role in this relationship. PressAcademia Procedia (PAP), V.3, p.952-971.

Permanent link to this document: $\underline{\text { http://doi.org/10.17261/Pressacademia.2017.677 }}$

Copyright: Published by PressAcademia and limited licenced re-use rights only.

\section{ABSTRACT}

The aim is to investigate effects of procedural justice on job satisfaction and new identification after merger and to investigate the mediatory role of new identification on this relationship. Methodology - Research participants of whom experienced the merger were reached by convenient sampling after the bank merger $(\mathrm{N}=143)$. The reliability, validity, normality, correlation and bootstrap analysis were used. Research findings show that procedural justice effects job satisfaction and new identification after the merger significantly and positively. However there is no mediation effect of the new identification after bank merger on this relationship. The findings show that for success in mergers the management must understand the importance of employees' job satisfaction and must evaluate the factors effecting job satisfaction with scientific methods.
\end{abstract}

Keywords: Procedural justice, job satisfaction, identification, mergers, bank mergers, mediation, bootstrapping.

JEL Codes: M10, G34, J28

\section{SÜREÇ ADALETININ, iş DOYUMU VE BANKA BiRLEŞMESi SONRASI YENi ÖZDEŞLEŞME ÜZERINDEKi ETKiLERI VE YENI ÖZDEŞLEŞMENIN BU iLIŞKIDEKI ARACI ROLÜ}

\section{ÖZET}

Banka birleşmelerinde, çalışanların süreç adaleti pozitif algısının, iş doyumu ve banka birleşmesi sonrası yeni özdeşleşme üzerindeki etkilerinin belirlenmesi ve bu etkide yeni özdeşleşmenin aracılık etkisinin incelenmesi amaçlanmıştır. Katılımcılar, banka birleşmesi sonrası, kolayda örnekleme metoduyla seçilerek bu araştırmanın örneklemini oluşturmuştur ( $N=143$ ). Güvenilirlik, geçerlilik, normal dağılım, korelasyon ve bootstrap analizi kullanılmıştır. Araştırma sonucunda süreç adaleti olumlu etkisinin, çalışanların banka birleşmesi sonrası yeni özdeşleşme ve iş doyumları üzerinde anlamlı düzeyde ve pozitif yönde etkili olduğunu göstermektedir. Ancak bu ilişkide, banka birleşmesi sonrası yeni özdeşleşmenin aracılık etkisi bulunmamıştır. Çalışma sonucu, yöneticilerin banka birleşmelerinin başarısı için çalışan memnuniyetinin önemini ve etkileyen faktörlerin bilimsel olarak ele alınması gerektiğini göstermektedir.

Anahtar Kelimeler: Süreç adaleti, iş doyumu, özdeşleşme, işletme birleşmeleri, banka birleşmeleri, bootstrap. JEL Kodları: M10, G34, J28 


\section{GíRiş}

İşletme birleşmelerinin başarısı için çalışanların iş doyumu çok önemlidir. Bu nedenle, çalışanın iş doyumunu etkileyen süreç adaleti ve çalışanın banka birleşmesi sonrası yeni kurum kimliğini benimsemesi çok önemlidir. Bu çalışmanın amacı çalışanların süreç adaleti algısının iş doyumu üzerinde ve banka birleşmesi sonrası yeni kurumla özdeşleşmesi üzerindeki etkileri incelemek ve yeni kurumla özdeşleşmenin süreç adaleti ile iş doyumu arasındaki ilişkisinde dolaylı (aracılık) etkisini incelemektedir. Bu kapsamda, yazarın yayınlanmamış doktora tezi baz alınarak yapılan bu çalışmada aşağıdaki soruların cevapları araştırılmaktadır.

Banka birleşmelerinde, banka birleşmesi sonrası yeni birleşik bankada çalışanların;

a) Süreç adaleti olumlu algısı, çalışanın iş doyumunu etkiler mi?

b) Süreç adaleti olumlu algısı, çalışanların yeni birleşik banka ile özdeşleşmelerini etkiler mi?

c) Çalışanların banka birleşmesi sonrası yeni birleşik banka ile özdeşleşmeleri, iş doyumlarını etkiler mi?

d) Süreç adaleti olumlu algıları, birleşik banka ile özdeşleşmeleri aracılığı ile iş doyumlarını etkiler mi? Başka bir deyişle, çalışanların yeni kurumla özdeşleşmelerinin, süreç adaleti algıları ile iş doyumları arasında aracılık etkisi var mıdır?

\section{LiTERATURE INCELEMESi}

\section{1. İşletme Birleşmeleri ve Süreç Adaleti}

Adalet, örgütlerin sahip olması gereken ilk erdem olarak kabul edilmiştir. Yöneticilerin adaletli ya da adil olmaları, örgütsel adalet kavramı ile ifade edilmektedir ${ }^{1}$.

Örgütsel adalet, eşitlik yaklaşımını temel almaktadır, bu yaklaşımda, çalışanlar, kendilerini örgüte sağladıkları katkı ile örgütün kendilerine sağladığı katkıyı karşılaştırarak, benzer işleri yapan diğer çalışanları ile kendilerini karşılaştırıp, değerlendirerek, örgüt yönetiminin adil olup olmadığına karar vermektedirler. Örgütsel faydanın çalışanlara adaletli bir biçimde dağıtııması "dağıtım adaleti” olarak tanımlanmaktadır ${ }^{2}$.

Örgütsel adalet olumlu algısı, çalışanların tutum ve davranışlarını olumlu etkilemekte, adaletsizlik algısı halinde ise (örneğin "ücretim aşırı derecede düşük ve diğer çalışanların çoğundan daha az ücret alıyorum" gibi ifadeler) "hırsızlık" dahil olumsuz davranışlara neden olmaktadır ${ }^{3}$.

Yöneticilerin örgüt kurallarını tüm çalışanlara adil ve istikrarlı bir şekilde uygulayarak, performans ve başarılarına göre nesnel bir biçimde ödüllendirmeleri halinde çalışanların dağıtım ve süreç adaleti algıları olumlu etkilenmektedir ${ }^{4}$.

Işletme birleşmeleri, yapı itibari ile olağanüstü değişikliklere, belirsizliğe, kadroların birleşmeleri nedeniyle, kadro değişikliklerine ve yeni kadrolara yol açmaktadır. Tüm bu süreç boyunca, işletme birleşmesi sürecindeki iki farklı kurum çalışanları tarafından sürecin adil bir şekilde yönetildiği algısı, çalışanın iş doyumu için önem taşımaktadır

Süreç adaleti olumlu algısı, çalışanın iş doyumunu ve işletme birleşmesi sonrası yeni kurumu ile özdeşleşmesini olumlu etkilediğinden, dolaylı olarak işletme birleşmesinin başarısını etkilemektedir.

İşletme birleşmelerinde süreç adaleti olumlu algısı, çalışanın kurumla özdeşleşmesini olumlu etkilemenin yanı sıra, çalışanın iş tatminini de olumlu etkilemektedir ${ }^{5}$.

Örgütsel adalet, "dağıtım adaleti” (ödüle dayalı), süreç adaleti ve etkileşim adaleti olarak tanımlanmaktadır ${ }^{6}$.

Süreç adaleti, karar alma süreçleri ve uygulamasını kapsamaktadır. Dağıtım adaleti ve süreç adaleti boyutları yapısal açıdan benzemektedirler. Dağıtım kararlarına ilişkin "süreçlerin" adil olup olmadığı ile ilgilidir. Süreç adaleti, örgütün tamamına bir bütün olarak gösterilen tepkiyi kapsamaktadır" ${ }^{7}$.

Leventhal, süreç adaletinin, çalışanın yönetsel kararların ve karar alma süreçlerinin adil olduğu algısı durumunda oluştuğunu ve çalışanın sürecin adil olduğuna inanması durumunda, kendisinin daha düşük ücret alması veya terfi edememesi gibi olumsuz bir durumda dahi, adil sürece inandığı için düşük ücret ve terfi alamamasını sorgulama olasılığının düştüğünü belirtmektedir ${ }^{8}$. 
Süreç adaleti, kararların alınmasında ve kuralların uygulanmasında kullanılan süreçlerin/işlemlerin adil olması, ödemelerin eksik veya fazla olmasının kontrolü, kararlara katılım, sonuçlar hakkında bilgi verme gibi işlemlerin çalışanlar arasında eşit paylaştıııması olarak tanımlanmaktadır. Süreç adaleti, dağıtım adaleti ile birlikte uygulanmalıdır ${ }^{9}$.

İ̧̧letme birleşmelerinin başarısızlık nedenleri arasında çalışanların belirsizlik ve stresten kaynaklanan sorunların çözümü için yöneticilerin çalışanın özdeşleşmesine ve özdeşleşmesini olumlu etkileyen süreç adaletinin sağlanabilmesi için işletme birleşme sürecinde gerekli çabayı göstermelidir.

İşletme birleşmelerinde, iptal edilen pozisyonlar, yeniden yerleştirmeleri vb nedeniyle çalışanların hakları etkilenmektedir ${ }^{10}$. İşletme birleşme sürecinde, çalışanların işlerini ve kariyerlerini etkileyen konularda bilgilendirilmeleri, haklarını ve işlerini etkileyen kararlara katılımları gerekmektedir. Işletmeler arasındaki güç farklılığı da pozisyonların yerleştirilmesini etkilemektedir $^{11}$.

İşletme birleşmelerinde, süreç adaletine uygun davranıldı̆̆ı algısı hem yeni kurumla özdeşleşmesini hem de dolaylı olarak çalışan memnuniyetini olumlu etkileyen çok önemli bir unsurdur.

Bu çalışmada süreç adaleti olumlu algısının, çalışanların iş doyumu üzerindeki etkileri bir örnek olay incelemesi ile araştırılmıştır. Bu araştırma kapsamında, ayrıca çalışanın yeni kurumu ile özdeşleşmesinin, iş doyumu ile süreç adaleti arasındaki ilişki üzerindeki indirekt (aracılık) etkisi de incelenmiştir.

Bu bağlamda, araştırmanın ana hipotezi ve araştırma modeli aşağıdaki gibi belirlenmiştir.

Hipotez: Süreç adaleti olumlu algısı, banka birleşmesi sonrası yeni kurumla özdeşleşmesi aracılığı ile çalışanın iş doyumunu olumlu etkilemektedir.

- Süreç adaleti iş doyumunu olumlu etkiler

- Süreç adaleti yeni özdeşleşmeyi olumlu etkiler.

- Yeni özdeşleşme, iş doyumunu olumlu etkiler.

- Yeni özdeşleşmenin, süreç adaleti ve iş doyumu ilişkisinde indirek (aracılık) etkisi vardır.

Şekil 1: "Süreç adaleti olumlu algısı, banka birleşmesi sonrası yeni kurumla özdeşleşmesi aracılığıyla, çalışanın iş doyumunu olumlu etkilemektedir." Hipotez Modeli

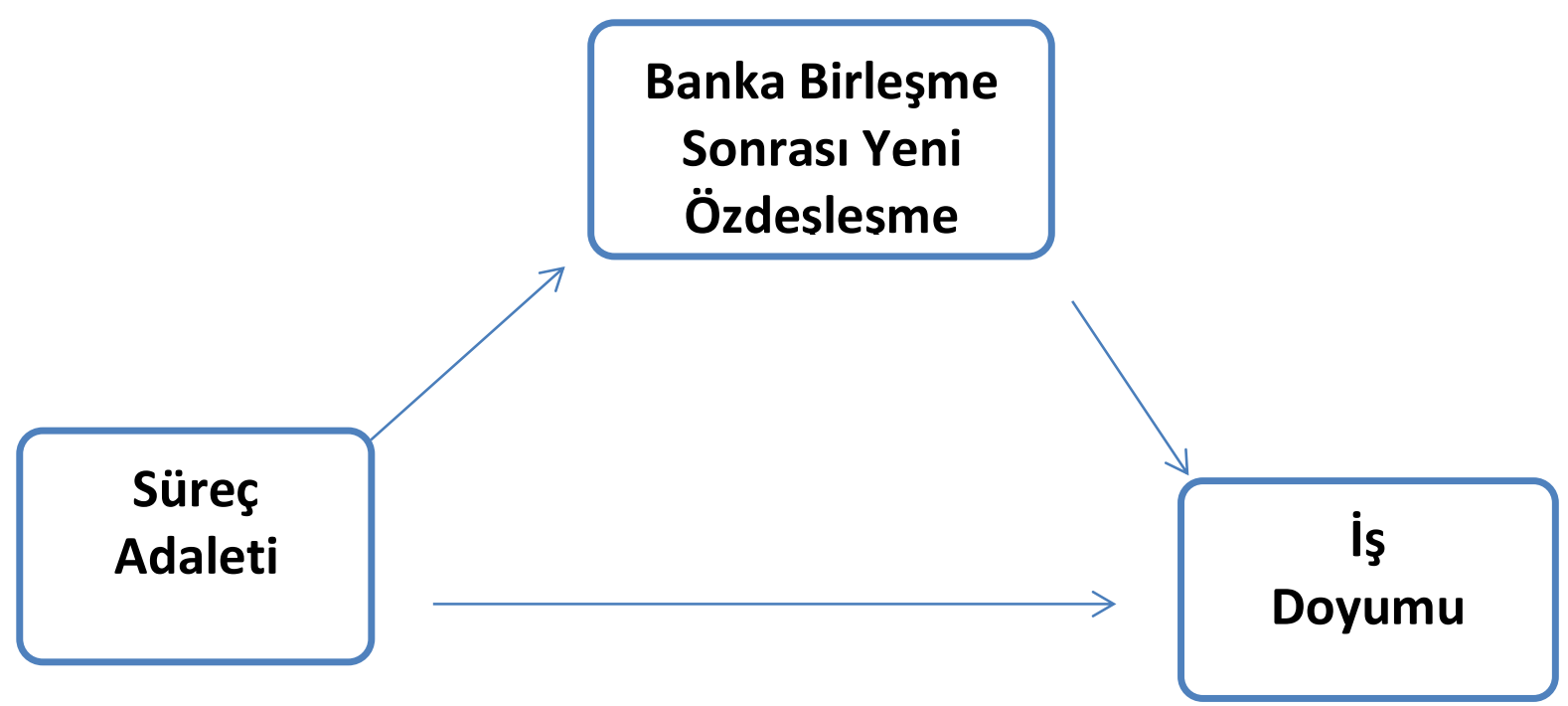




\section{2.işletme Birleşmeleri ve Özdeşleşme}

İşletme birleşmeleri, yapısı itibari ile çok büyük ve hızı değişiklikleri kapsayan, belirsizlik içeren dönemler olup, çalışanın kurumları ile özdeşleşmelerini etkilemektedir ${ }^{12}$. Belirsizlik çalışanın veriminin düşmesi ve işten ayrılma niyetinin artmasına da neden olmaktadır ${ }^{13}$.

Özdeşleşme, çalışanın daha yüksek performans göstermesinin ${ }^{14}$ yanı sıra, işletmelerin başarısızlık nedenlerinden birisi olan belirsizliği de azaltmaktadır ${ }^{15}$.

Diğer yandan, çalışan kurum özelliklerini benimsediği ölçüde, kurum kimliğine yönelik davranmaktadır (Ashford, 2000). Çalışanlar, benlik tanımlamalarını kurumla özdeşleşerek yaparak, örgüte "psikolojik bağı”" hale gelerek, örgütün başarısını ve başarısızlıklarını paylaşmaktadır ${ }^{16}$.

Bu nedenlerle, çalışanın yeni kurumla özdeşleşmesi, işletmenin başarısı için çok önemlidir ${ }^{17}$.

\section{3. İşletme Birleşmeleri ve iş̧ Doyumu}

İş doyumu, çalışanın motivasyonu ile ilgili ilk on faktörden birisi olarak tespit edilmiştir ${ }^{18}$. Motivasyon ise iş doyumu ile adalet algııını olumlu etkileyen güçlü stratejileri oluşturmakta, çalışan bağlılığını artırmaktadır. Motivasyon aynı zamanda kalite düzeyini yükseltmekte ve iş stresini azaltmaktadır ${ }^{19}$. Tüm bu unsurlar dolaylı olarak iş doyumunu olumlu olarak etkilemektedir ${ }^{20}$.

Süreçleri kontrol olanağı verilen çalışanların, iş doyumu daha yüksektir çünkü süreç kontrolü verilen tarafların kararların adil olduğu algısı, kontrol olanağı verilmeyen çalışanlara göre daha yüksektir, süreci kontrol edemeyen çalışanlar sonuçlardan memnun olmamaktadır ${ }^{21}$.

Dağıtım adaleti, ücret doyumu ve genel iş doyumunu olumlu etkilemektedir ${ }^{22}$.

Adalet olumlu algısı, çalışanın iş doyumunu olumlu etkilemektedir ${ }^{23}$.

Süreç adaleti, iş doyumunu olumlu etkilemektedir ${ }^{24}$.

\section{VERI VE YÖNTEM}

Çalışanın süreç adaleti olumlu algısının, iş doyumuna ve banka birleşmesi sonrası yeni özdeşleşme algısına etkisini ve ayrıca süreç adaleti olumlu algısının, çalışanın iş doyumu üzerindeki etkisinde, çalışanın banka birleşmesi sonrası yeni kurumla özdeşleşmesinin aracılık etkisinin rolünün araştırıldığı bu çalışmada kullanılan yöntemler aşağıdaki gibidir.

Araştırmada literatür taraması sonucu çeşitli kaynaklardan yararlanılarak ölçekte kullanılacak sorular tespit edilerek, soru formu oluşturulmuştur. Veri toplama aracı olarak anket kullanılmıştır.

Tüm ölçekler bir anket formu içinde kullanılmış ve demografik unsurlar çalışanlar arasında mevcut farklııılar için (örneğin cinsiyet, yaş grubu, kıdem ve eğitimi gibi) kullanılmıştır.

$\mathrm{Bu}$ araştırma kesitsel (cross-sectional) bir araştırmadır. Kesitsel araştırmalarda ise genişlemesine (uzamsal-izleme) araştırmalarının tersine, kısa zaman diliminde bir kez veri toplanmaktadır ${ }^{25}$.

Kesitsel araştırma kapsamında, iki bankanın birleşmesi sonrası veriler bir kez toplanmıştır. Ölçme aracı olarak tüm ölçeklerde 5’li Likert tipi ölçek kullanılmıştır.

1-Kesilikle Katılmıyorum,

2-Katılmıyorum,

3-Ne Katılıyorum, Ne Katılmıyorum,

4-Katıliyorum,

5-Kesinlikle Katılıyorum.

Araştırma bulguları, katılımcılardan elde edilen veriler üzerinde SPSS 21.0 paket programı kullanılarak gerçekleştirilen analizlerin sonucunda elde edilmiştir.

Elde edilen verilerin analizinde, modelde verilen değişkenler bazında geçerlilik ve güvenilirlik, verilerin normalliği, korelasyon ve regresyon analizinden yararlanılmıştır. 


\section{Araştırma Değişkenleri}

Araştırmada üç grup değişken olup, bağımsız değişkenlerin, bağımlı değişkene etkisi ve bu etkiye aracı değişkenin aracılık rolü araştırılmıştır.

Araştırmanın değişkenleri;

- bağımlı değişkeni, iş doyumu olup,

- iş doyumunu etkileyen aracı değişken, işletme birleşme sonrası yeni özdeşleşme,

- bağımsız değişken ise süreç adaleti

olarak belirlenmiştir.

İş Doyumu ölçeği iki ifadenin hazırlanmasında Hackman ve Oldham ${ }^{26}$ ölçeğinden yararlanılmıştır.

a) Genel olarak söylemek gerekirse, işimden çok memnunum.

b) işimde, faydalı/anlamlı bir şeyler yaptığım duygusu beni memnun eder.

İşletme Birleşme Sonrası Yeni Özdeşleşme ölçeği aşağıda verilen üç ifade, van Knippenberg ve arkadaşlarının ${ }^{27}$ ölçeğinden yararlanılarak hazırlanmıştır.

a) Kendimi, yeni bankamla özdeşleştirdiğime inanıyorum.

b) Birisi, yeni bankamı eleştirirse, şahsıma hakaret edilmiş gibi hissederim.

c) Yeni bankamla güçlü bağlarım olduğunu düşünüyorum.

Süreç Adaleti algısı aşağıda verilen altı ifadesi, Moorman ${ }^{28}$ ölçeğinden yararlanılarak, hazırlanan ölçek kullanılmış olup, ölçek soruları aşağıdaki gibidir.

a) Yönetimin, görev değişiklikleri öncesi çalışanların çekincelerin dikkate aldığını düşünüyorum.

b) Yönetimin, görev değişikliği kararlarında, bize mantıkla açıklamalar yaptığına inanıyorum.

c) Yönetimin, yeniden yapılanma ile ilgili kararlarında, bana adil davranıldığına inanıyorum.

d) İş ile ilgili alınan kararların, etkilenen tüm çalışanlara uygulandığını düşünüyorum.

e) Çalışanlar talep ettiğinde, yönetimin aldığı kararları açıkladığını ve ilave bilgi verdiğine inanıyorum.

f) Yeniden yapılanma ve uygulama ile ilgili bilgilerin, çalışanlara zamanında verilmesini sağlamak için yeni süreçlerin uygulanmaya konduğunu düşünüyorum.

Niehoff ve Moorman ${ }^{29}$ tarafından geliştirilen örgütsel adalet ölçeği, dağıtım adaleti, işlem adaleti, süreç adaleti, etkileşim adaleti alt boyutlarını kapsamaktadır.

Örgütsel adalet kavramı son yıllarda artarak araştırılmasına rağmen mevcut ölçeklerin yeterince geçerli olmadığı endişeleri dile getirilmiştir ${ }^{30}$.

Literatürde kullanılan diğer adalet ölçekleri aşağıda verilmektedir:

- Price ve Mueller ${ }^{31}$ dağıtım adaleti ölçeği,

- Greenberg ve Baron'un ${ }^{32}$, süreç adaleti algısı ölçümü ölçeği,

- Karambayya ve Brett'in iş görenlerin örgütsel adalet algısı ölçeği,

- Donovan, Drasgow ve Munson ${ }^{33}$, çalışanların iş ortamlarındaki ilişkileri, genel olarak, ne denli adil algıladıklarını değerlendiren ölçeği,

- Folger ve Konovsky ${ }^{34}$ tarafından geliştirilen örgütsel adalet ölçeği,

- Hoy ve Tarter $^{35}$ tarafından geliştirilen örgütsel adalet ölçeği ve 
- Ambrose, M.L., Schminke, M. ${ }^{36}$, tarafından geliştirilen örgütsel adalet ölçeği kullanılmaktadır.

Bağımsız değişken (süreç adaleti olumlu algısının, bağımlı değişken (iş doyumu) üzerindeki etkisinde, aracı değişkenin (yeni kurumla özdeşleşmesinin) aracılık rolü incelenmiştir.

\section{Ana Kütle ve Örneklem}

Araştırmanın ana kütlesini TEB ve Fortis banka birleşmesini yaşayan tüm çalışanlar oluşturmaktadır. İşletme birleşmeleri literatür çalışmasında, özellikle birleşme sonrası, kurumların, araştırmacılara izin vermediği, bu nedenle (öncesi ve sonrasını kapsayan) çok az sayıda araştırma olduğu belirtilmiştir.

Bankacılık sektöründe ise bilgi paylaşımı gizliliği nedeniyle araştırma yapılması daha da güçtür. Nitekim, bir çok bankaya başvurulmasına karşın, araştırma için izin alınamamıştır. Uzun süren çabalar sonucu sadece ilgili bankadan izin alınabilmiştir.

Birleşik banka genel müdürlük binası, üç departmanda toplam 200 çalışana anket formu çıktıları dağıtılarak, (toplantı, yıllık izin, eğitim vb. nedeniyle yerinde olmayanlar dışında) o sırada ulaşılabilen ve arzu edenlerin ankete katılımı sonucu geri dönen 147 anket formundan, 4 kişi banka birleşmesi sonra işe başladığı için 143 anket formu değerlendirmeye alınmıştır. Özellikle bankacılık sektöründe, diğer sektörlere göre daha da zor olan söz konusu iznin alınabilmiş olması ve izin alınan gün uygulanan kolayda örnekleme yöntemi ile yapılan çalışma sonucu elde edilen söz konusu 143 anket formu, kabul edilebilir örnek büyüklüklerine uygundur ${ }^{37}$.

\section{Araştırma Değişkenleri Ölçekleri İfadeleri Güvenilirlik Analizleri (Cronbach Alfa Katsayı Değerleri)}

Tüm değişkenlerin güvenilirliklerini ölçmek için Cronbach Alfa Katsayısı (Cronbach Alpha Coefficient- $\alpha$ ) incelenmiştir. Ankette yer alan soruların birbiri ile olan tutarlılığı ve kullanılan ölçeğin ilgilenilen sorun/kavramı ne derece ölçtüğü bu değer aracılığıyla ortaya konmuştur.

Faktörlerin içsel tutarlııklarının hesaplanmasında Cronbach Alpha değeri kullanılmıştır. Faktörlere ait güvenilirlik katsayısı 0.67 ile 0.91 arasında değişmektedir.

Ölçeğin genel durumunun güvenilirlik katsayısının ise 0.89 olduğu görülmektedir. Bu değer literatürde öngörülen 0.60 alt limit kriterini sağlamaktadır ${ }^{38}$. Dolayısıyla, araştırma verilerine ait aşağıdaki tablolarda verilen sonuçlar, araştırmada kullanılan ölçeğin içsel tutarlılığa sahip olduğunu ortaya koymaktadır.

Tablo.1: Araştırma Değişkenleri Ölçekleri Güvenilirlik Analizi (Cronbach Alfa) Katsayı Değerleri

\begin{tabular}{|l|c|c|}
\hline Ölçek & Soru SayıSı & Güvenilirlik Katsayısı \\
\hline $\begin{array}{l}\text { Banka Birleşme Sonrası Yeni Kurumla } \\
\text { Özdeşleşme }\end{array}$ & 3 & 0.678 \\
\hline İ̧̧ Doyumu & 2 & 0.691 \\
\hline Süreç Adaleti & 6 & 0.910 \\
\hline
\end{tabular}

\section{Araştırma Değişkenleri Ölçekleri Geçerlilik Analizi}

Ölçeklerin güvenilirlik analizleri tespit edildikten sonra yapılan geçerlilik analizleri aşağıda verilmiştir. Araştırma modelinin geçerliliği, yani kullanılan ölçeklerin gerçekten ölçüm aracının ölçmeyi amaçladığı ölçebilirliği sadece istatistiksel analizler ile değil geçerlilik analizleri ile yapılabilir. Geçerlilik analizleri çerçevesinde içerik (kapsam) geçerliliği ve yapı geçerliği analizlerinin yapılması gerekmektedir ${ }^{39}$.

\section{Araştırma Değişkenleri Ölçekleri İçerik (Kapsam) Geçerliliği}

Araştırmanın modelinde değişkenler ve değişkenlerin ölçümü için kullanılan ölçekler uluslararası literatürde değişik kaynaklardan yararlanılarak uyarlanıp araştırmada kullanılmıştır. Soru formunda kullanılan ifadelerin daha anlaşılır olmasını sağlamak için, anket formu hazırlık sürecinde, akademisyenlere danışılarak, yeniden gözden geçirilen ölçek soruları önce İngilizce'den Türkçe'ye çevrilmiştir. Türkçe'ye çevrilen ölçekler daha sonra tekrar İngilizce'ye çevrilerek, iki İngilizce metin karşılaştırılarak anket formu hazırlanmıştır. Hazırlanan anket formu, bir grup banka çalışanı ile yapılan ilk örnek çalışma egzersizi sonucu tekrar gözden geçirilmiş ve netlik (tercümeden kaynaklanan) için bazı küçük kelime değişiklikleri yapıldıktan sonra uygulanmıştır. 


\section{Araştırma Değişkenleri Ölçekleri Yapı Geçerliliği (Faktör Analizi)}

Faktör analizi, aynı yapıyı ölçen çok sayıda değişkenden, az sayıda ve tanımlanabilir nitelikte anlamlı değişkenler elde etmeye yönelik çok değişkenli bir istatistiktir ${ }^{40}$.

Faktör analizinin en önemli amaçlarından biri değişkenler arasındaki karşılıklı bağımlılığın temelini araştırmaktır. Faktör ağırlıkları faktörün değişkeni ölçmedeki önemini gösteren ölçüdür ${ }^{41}$.

Faktör analizinde örneklem yeterliliğini test etmek için Kaiser-Meyer-Olkin (KMO-örnekleme yeterliliği istatistiği) ve Bartlett Test of Sphercity (Bartlett Küresellik Testi) kullanılmaktadır ${ }^{42}$.

Yapı geçerliliği için tüm ölçeklere değişken bazında faktör analizi yapılmıştır.

Veri setinin, faktör analizi için uygun olup olmadığını belirlemek için öncelikle KMO değerinin 0,50 den büyük olması gerekmektedir.

Kaiser-Maiyer-Olkin (KMO) örneklem yeterliliği ölçütü değerlendirilir. Gözlenen korelasyon katsayıları büyüklüğü ile kısmi korelasyon katsayılarının büyüklüğünü karşılaştıran bir indekstir. KMO ile veri setinin faktör analizi için uygunluğu testinde, $\mathrm{KMO}, 0$ ve 1 arasında bir değerdir. Oran ne kadar yüksekse veri seti analiz yapmak için o kadar uygundur demektir. KMO değerleri aşağıda verilmektedir ${ }^{43}$.

\begin{tabular}{|c|c|}
\hline KMO DEĞERi & YORUM \\
\hline 0,9 & Mükemmel \\
\hline 0,8 & Çok iyi \\
\hline 0,7 & İyi \\
\hline 0,6 & Orta \\
\hline 0,5 & Zayıf \\
\hline 0,50 'nin altı & Kabul Edilemez \\
\hline
\end{tabular}

Bartlett Testi (Barlett test of Sphericity) değerlendirilir; Bu test Korelasyon matrisinde değişkenlerin en azından bir kısmı arasında yüksek oranlı korelasyonlar olduğu olasılığını test eder. Veri setinin faktör analizi için uygun olduğunu göstermektedir ${ }^{44}$.

Bu çalışmada faktör analizi için SPSS 21 paket programı kullanılmıştır. Araştırma değişkenleri faktör analizi sonuçları ve faktör yükleri tabloları aşağıda verilmektedir.

Tablo 2: Banka Birleşme Sonrası Yeni Kurumla Özdeşleşme-Faktör Analizi Faktör Yükleri, Açıklanan Varyans, KMO ve Bartlett Test Sonuçları

\begin{tabular}{|c|c|c|c|}
\hline Faktörün Adı & \multicolumn{2}{|l|}{ Soru ifadesi } & $\begin{array}{c}\text { Faktör } \\
\text { Ağırlıkları }\end{array}$ \\
\hline \multirow{3}{*}{$\begin{array}{l}\text { Banka Birleşme Sonrası } \\
\text { Yeni Kurumla } \\
\text { Özdeşleşme }\end{array}$} & \multicolumn{2}{|c|}{ Kendimi, yeni bankamla özdeşleştirdiğime inanıyorum. } & 0.746 \\
\hline & \multicolumn{2}{|c|}{ Birisi, yeni bankamı eleştirirse, şahsıma hakaret edilmiş gibi hissederim. } & 0.810 \\
\hline & \multicolumn{2}{|c|}{ Yeni bankamla güçlü bağlarım olduğunu düşünüyorum. } & 0.800 \\
\hline \multicolumn{3}{|c|}{ Toplam Açıklanan Varyans Oranı } & 61.754 \\
\hline \multicolumn{3}{|c|}{ Kaiser - Meyer - Olkin Ölçek Geçerliliği } & 0.661 \\
\hline \multirow{2}{*}{\multicolumn{2}{|c|}{ Bartlett's Küresellik Testi }} & Ki-Kare & 70.421 \\
\hline & & p Değeri & 0.000 \\
\hline
\end{tabular}

KMO değeri kabul edilebilir sınır olan 0.66 olarak tespit edilmiş, Bartlett küresellik testi de 0,50'nin üzerinde olduğu ve 0,05 önem derecesinde anlamlı olduğundan veri seti faktör analizine uygun bulunmuştur. Bulunan KMO katsayısı verilerin analize uygun olduğunu göstermektedir. Varyansı açıklama oranının 0.50 ve üzerinde olması ölçütü esas alınmıştır. Toplam açıklanan varyans $\% 70.421$ olarak bulunmuştur. 
Tablo.3: İ̧̧ Doyumu -Faktör Analizi -Faktör Yükleri, Açıklanan Varyans, KMO ve Bartlett Test Sonuçları

\begin{tabular}{|l|l|c|}
\hline \multirow{2}{*}{ Faktörün Adı } & Soru Ifadesi & $\begin{array}{c}\text { Faktör } \\
\text { Ağırlıkları }\end{array}$ \\
\hline \multirow{2}{*}{ İş Doyumu } & Genel olarak söylemek gerekirse, işimden çok memnunum. & 0.876 \\
\cline { 2 - 3 } & İ̧̧imde, faydalı/anlamlı bir şeyler yaptığım duygusu beni memnun eder. & 0.876 \\
\hline Toplam Açıklanan Varyans Oranı & 76.656 \\
\hline Kaiser - Meyer - Olkin Ölçek Geçerliliği & 0.500 \\
\hline \multirow{2}{*}{ Bartlett's Küresellik Testi } & Ki-Kare & 46.982 \\
\cline { 2 - 3 } & p Değeri & 0.000 \\
\hline
\end{tabular}

KMO değeri kabul edilebilir sınır olan 0.50 olarak tespit edilmiş, Bartlett küresellik testi de 0,50 'nin üzerinde olduğu ve 0,05 önem derecesinde anlamlı olduğundan veri seti faktör analizine uygun bulunmuştur. Bulunan KMO katsayısı verilerin analize uygun olduğunu göstermektedir. Varyansı açıklama oranının 0.50 ve üzerinde olması ölçütü esas alınmıştır. Toplam açıklanan varyans \%76.656 olarak bulunmuştur.

Tablo.4: Süreç Adaleti -Faktör Analizi-Faktör Yükleri, Açıklanan Varyans, KMO ve Bartlett Test Sonuçları

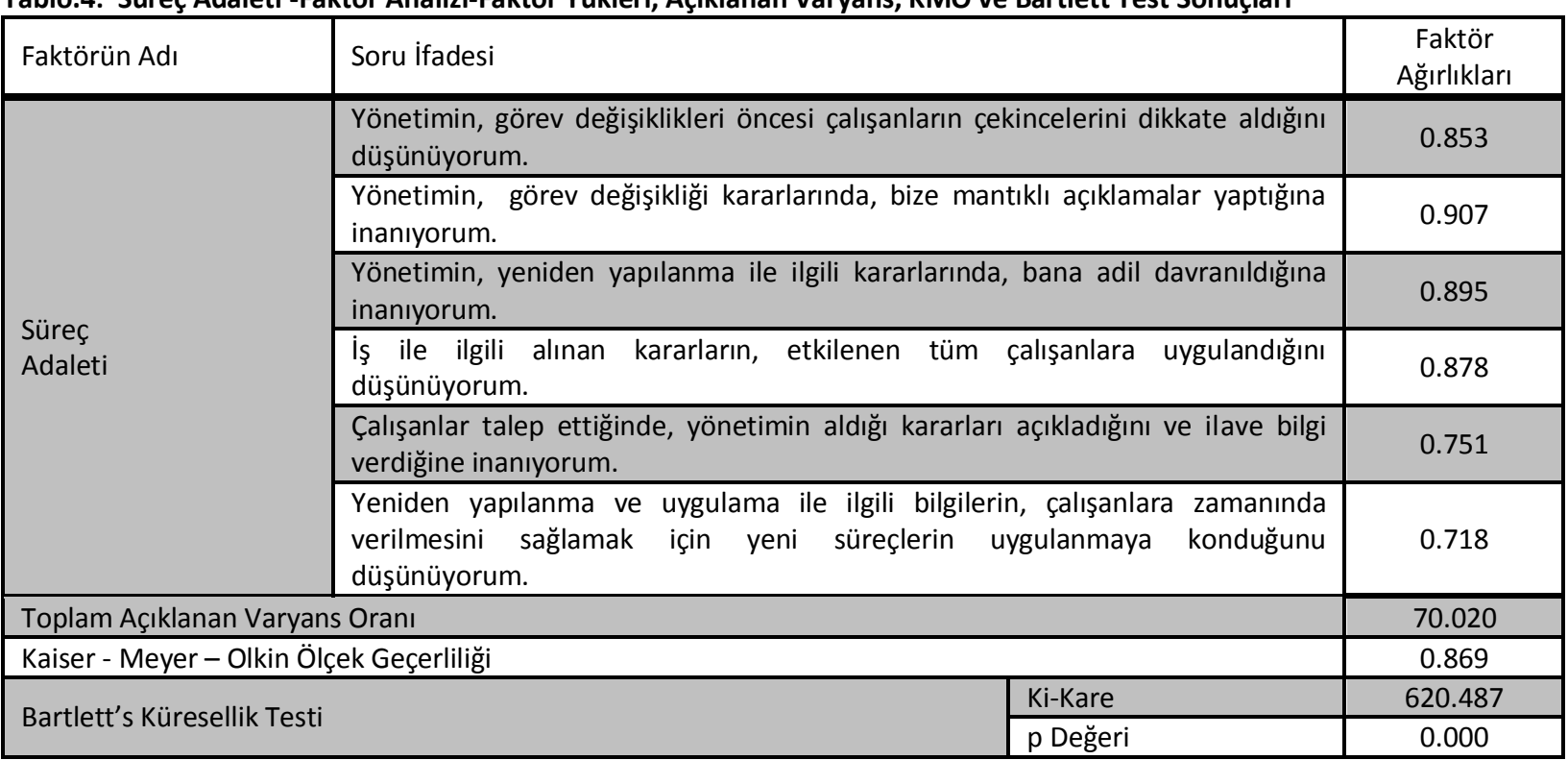

KMO değeri kabul edilebilir sınır olan 0.86 olarak tespit edilmiş, Bartlett küresellik testi de 0,50 'nin üzerinde olduğu ve 0,05 önem derecesinde anlamlı olduğundan veri seti faktör analizine uygun bulunmuştur. Bulunan KMO katsayısı verilerin analize uygun olduğunu göstermektedir. Varyansı açıklama oranının 0.50 ve üzerinde olması ölçütü esas alınmıştır. Toplam açıklanan varyans \%70.020 olarak bulunmuştur. Sonuç olarak, Bartlett 'in küresellik testine göre de veri setinin faktör analizi için uygun olduğu belirlenmiştir. Araştırma, işletme birleşmeleri ile ilgili olarak bankacılık sektörü, banka birleşmeleri kapsamında, birleşen TEB ve Fortis Bank birleşmesi sonucu 'Birleşik Banka' çalışanlarına uygulanan araştırma konusu birleşen bankalara ait özet bilgiler aşağıdaki gibidir.

'Birleşik Banka' çalışanlarına yönelik araştırma bulgularına geçmeden önce BDDK'nın birleşme kararını takiben, TEB Birleşik Banka, 31.Mart.2011 ilk çeyrek konsolide sunumunda verilen bilgilere göre; 'Birleşik Banka'yı (teb.com.tr) ${ }^{45}$, oluşturan iki farklı banka (TEB ve Fortis Banka) Birleşik Banka özet bilgileri aşağıda verilmektedir;

“TEB ve Fortis Bankaları Birleşmesi, BDDK'nın, 12 Şubat 2011 tarih ve 27844 sayılı Resmi Gazetede yayınlanan, 10 Şubat 2011 tarih ve 4048 sayılı sayılı Kararı ile, Fortis Bank A.Ş.'nin, 25 Ocak 2011 tarihinde Türk Ekonomi Bankası A.Ş.'ye tüm aktif pasifi ile kül halinde devredilmesine izin verilmiştir. Devir Kararı 14 Şubat 2011 tarihinde İstanbul Ticaret Sicil 
Memurluğunda tescil edilmiştir. Fortis Bank A.Ş. ünvanı, devir sonucu birleşmek suretiyle tasfiyesiz infisah ettiğinden İstanbul Ticaret Sicilindeki kaydının silindiği 14 Şubat 2011 tarihinde tescil ve ilan edilmiştir (bddk.org.tr)".

TEB Tarihçe-“1927 Kocaeli Bankası olarak kurulan, Türk Ekonomi Bankası A.Ş. 1982 Çolakoğlu Grubu tarafından satın alındı, Türk Ekonomi Bankası adı altında ulusal banka olarak faaliyetlerine başladı. 2005'de BNP Paribas ile ortaklık anlaşması imzalandı. BNP Paribas ve Çolakoğlu Grubu bankada \%42,13 dolaylı pay sahibi olarak, 2011 Fortis ile birleşti (teb.com.tr) ${ }^{46}$."

Fortis Bank Tarihçe- "Fortis Bank, 1964 Amerikan Türk Ticari Bankası olarak kuruldu, 2005'de Fortis Bank SA/NV hisselerin \%89.34'ünü aldı, 2008 Belçika Hükümeti Fortis Bank Belçika'nın \%99,93\%'ünü, Fortis Bank Türkiye'nin ana firmasını satın aldı. Fortis Bank Belçika'nın hissesinin \%75'inin satışı ile ilgili BNP Paribas ile MoU anlaşması imzaladı. 2009 Fortis Bank Belçika'nın \%75'i BNPParibas'a satıldı ve BNPParibas ana hissedar konumuna geldi (\%94,11). 2011 TEB ile birleşti".

\section{Araştırmanın Tanımlayıcı İstatistik Analizleri}

Araştırma katılımcılarının, yaş dağılımı, \%51'i 31 ile 40 yaş aralığında, \%32.2'si 20 ile 30 yaş aralığındadır. Katııımcıların \%56.6'sı evli olup, eğitim dağılımları ise \%70.6'sı lisans, \%11.9'u ise yüksek lisans mezunudur. Katılımcıların, \%47.6'sı, 1 ile 5 yıl arası banka birleşmesi öncesi banka deneyimlidir. Araştırmaya katılanların \%55.9'u kadın, \%39.9 erkek çalışandan oluşmaktadır. Araştırmaya katılan 143 kişiye ilişkin bulgular aşağıdaki tabloda verilmektedir.

Tablo.5: Araştırmaya Katılanlardan ilgili Sorulara Cevap Veren Kişilere Ait Özellikler

\begin{tabular}{|c|c|c|}
\hline Gruplar & Frekans ( $n=143)$ & Yüzde (\%) \\
\hline \multicolumn{3}{|l|}{ Cinsiyet } \\
\hline Kadın & 80 & 55.9 \\
\hline Erkek & 57 & 39.9 \\
\hline \multicolumn{3}{|l|}{ Yaş } \\
\hline $20-30$ Yaş Aralığı & 46 & 32.2 \\
\hline $31-40$ Yaş Aralığı & 73 & 51.0 \\
\hline 41 - 50 Yaş Aralığı & 15 & 10.5 \\
\hline 51 Yaş ve Üzeri & 4 & 2.8 \\
\hline \multicolumn{3}{|l|}{ Medeni Durum } \\
\hline Evli & 81 & 56.6 \\
\hline Bekar & 51 & 35.7 \\
\hline Diğer & 6 & 4.2 \\
\hline \multicolumn{3}{|l|}{ Eğitim Düzeyi } \\
\hline Lise & 5 & 3.5 \\
\hline Önlisans & 10 & 7.0 \\
\hline Lisans & 101 & 70.6 \\
\hline Yüksek Lisans & 17 & 11.9 \\
\hline Doktora & 2 & 1.4 \\
\hline \multicolumn{3}{|c|}{ Banka Birleşme Öncesi Bankada Çalışılan Süre } \\
\hline $1-5$ & 68 & 47.6 \\
\hline $6-10$ & 40 & 28.0 \\
\hline $11-20$ & 25 & 17.5 \\
\hline $21-30$ & 4 & 2.8 \\
\hline
\end{tabular}

\section{Araştırma Değişkenleri Ölçekleri iffadeleri Minimum, Maksimum ve Ortalama Değerleri}

Değişken bazında, aşağıdaki tabloda en yüksek ortalamanın 4,49 ile iş doyumu olduğu görülmektedir. 
Tablo.6: Araştırma Ölçekleri Değişkenleri-Ortalama Değerleri ( $N=143)$

\begin{tabular}{|c|c|c|c|}
\hline & Yeni Özdeşleşme & iş Doyumu & Süreç Adaleti \\
\hline Mean & 4,23 & 4,49 & 4,36 \\
\hline
\end{tabular}

Bu da iş doyumundan katılımcıların oldukça memnun olduğunu göstermektedir.

Nitekim, 143 katılımcının ölçekte bulunan ifadelere ilişkin değerleri incelendiğinde en yüksek ortalamaya sahip ifadenin "Işsimde, faydalı/anlamlı bir şeyler yaptığım duygusu beni memnun eder."

ifadesi olduğu görülmektedir.

Yapılan güvenilirlik analizi sonucunda, araştırma değişkenleri ölçek ifadelerine ait, minimum, maksimum, aritmetik ortalama ve örnek büyüklüğü aşağıdaki tabloda verilmiştir.

Tablo.7: Araştırma Değişkenleri Ölçekleri ifadeleri Minimum, Maksimum ve Ortalama Değerleri ( $\mathrm{N}=143$ )

\begin{tabular}{|c|c|c|c|c|}
\hline ifadeler & & Minimum & Maksimum & Ortalama \\
\hline 1. & Yeni bankamla güçlü bağlarım olduğunu düşünüyorum. & 0 & 5 & 4.25 \\
\hline 2. & Önceki bankamla, kendimi, daha güçlü özdeşleştirdiğime inanıyorum. & 1 & 5 & 3.24 \\
\hline & $\begin{array}{l}\text { Önceki bankamı, birisi eleştirdiğinde, şahsıma hakaret edilmiş gibi } \\
\text { hissederdim. }\end{array}$ & 0 & 5 & 3.32 \\
\hline 4. & Önceki bankamla, daha güçlü bağlarım olduğunu düşünüyorum. & 1 & 5 & 3.24 \\
\hline 5. & Genel olarak söylemek gerekirse, işimden çok memnunum. & 0 & 5 & 4.38 \\
\hline 6. & İşimde, faydalı/anlamlı bir şeyler yaptığım duygusu beni memnun eder. & 1 & 5 & 4.60 \\
\hline 7. & $\begin{array}{l}\text { Yönetimin, görev değişiklikleri öncesi çalışanların çekincelerini dikkate aldığını } \\
\text { düşünüyorum. }\end{array}$ & 2 & 5 & 4.29 \\
\hline & $\begin{array}{l}\text { Yönetimin, görev değişikliği kararlarında, bize mantıklı açıklamalar yaptığına } \\
\text { inanıyorum. }\end{array}$ & 1 & 5 & 4.35 \\
\hline & $\begin{array}{l}\text { Yönetimin, yeniden yapılanma ile ilgili kararlarında, bana adil davranıldığına } \\
\text { inanıyorum. }\end{array}$ & 1 & 5 & 4.39 \\
\hline & $\begin{array}{l}\text { İ̧̧ ile ilgili alınan kararların, etkilenen tüm çalışanlara uygulandığını } \\
\text { düşünüyorum. }\end{array}$ & 2 & 5 & 4.38 \\
\hline & $\begin{array}{l}\text { Çalışanlar talep ettiğinde, yönetimin aldığı kararları açıkladığını ve ilave bilgi } \\
\text { verdiğine inanıyorum. }\end{array}$ & 0 & 5 & 4.41 \\
\hline & $\begin{array}{l}\text { Yeniden yapılanma ve uygulama ile ilgili bilgilerin, çalışanlara zamanında } \\
\text { verilmesini sağlamak için yeni süreçlerin uygulanmaya konduğunu } \\
\text { düşünüyorum. }\end{array}$ & 0 & 5 & 4.36 \\
\hline
\end{tabular}

\section{Araştırma Ölçekleri Normal Dağııım Analizi}

Araştırmalarda istatistik analizlerine başlamadan önce verilerin normal dağılım olup olmadığına bakılmalıdır. Uygulanacak istatistik yöntemleri verilerin normal dağılım göstermediğine bağıı olarak farklı olabilmektedir.

Verilerin normal dağılım gösterip göstermediği histogramlara bakılarak da söylenebilir ancak bu öznel bir değerlendirmeye dayanmaktadı ${ }^{47}$. Bu nedenle bir dağılımın normal olup olmadığını verilerin çarpıklık ve basıklık değerlerine bakılarak, çarpıklık katsayısının (+/- 1 sınırları içinde, basıklık katsayısı +/- 3 (ve/veya +/-2) aralığında kalması halinde normal dağııım sınırları içinde olmaktadır.

Ayrıca Kolmogorov-Smirnov ve Shapiro-Wilks testleri ile de tespit edilebilmektedir. Örneklemin 50 'den az olması durumunda, Sharipo Wilks testi sonucunun daha doğru olacağı belirtilmektedir ${ }^{48}$. $50^{\prime}$ den büyük olduğu için KolmogovSimirnov testi yapılmıştır. Bu test sonuçlarında, $p$ değerinin istatistiksel olarak anlamsız $(p>0,5)$ çıkması halinde, verilerin normal dağılım gösterdiği, $p$ değerinin $(p<0,5)$ çıkması halinde ise dağılımın normal dağılmadığı söylenebilir.

Test sonuçlarına göre normal dağılım halinde parametrik ölçüm teknikleri, normal olmaması halinde ise non-parametrik (parametrik olmayan) testlerin kullanılması gerekmektedir. 
Tablo.8: Normal Dağılım Tablosu ( $\mathrm{N}=143$ )

\begin{tabular}{|l|c|c|}
\hline Ölçek ve Boyutları & Kolmogorov - Smirnov Z & p Değeri \\
\hline Banka Birleşme Sonrası Yeni Kurumla Özdeşleşme & 2.156 & 0.000 \\
\hline İ̧̧ Doyumu & 2.794 & 0.000 \\
\hline Süreç Adaleti & 2.025 & 0.001 \\
\hline
\end{tabular}

Test sonucuna göre ölçek ve boyutları bakımından grupların normal dağııım göstermediği $(p<0.05)$ görülmektedir. Bu nedenle analizler non-parametrik teknikler kullanılarak yapılmıştır.

\section{Araştırma Değişkenleri Spearman Korelasyon Analiz Sonuçları}

Araştırmamızda, veriler normal dağılım göstermediği için tüm değişkenler arasındaki ilişki analizi için Spearman korelasyon analizi tekniğinden yararlanılmıştır.

Tablo.9: Tüm Değişkenler Spearman Korelasyon Tablosu - Özdeşleşme, İ̧̧ Doyumu, Süreç Adaleti Değişkenleri

\begin{tabular}{|c|c|c|c|c|c|}
\hline N 14 & & & 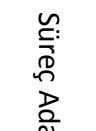 & $\begin{array}{c}\text { Birleşme } \\
\text { Sonrası Yeni }\end{array}$ & 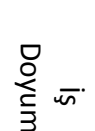 \\
\hline & Süreç Adaleti & $\begin{array}{l}\text { Correlation } \\
\text { Coefficient } \\
\text { Sig. (2-tailed) }\end{array}$ & 1 & $\begin{array}{c}451^{* *} \\
0\end{array}$ & $\begin{array}{c}487^{* *} \\
0\end{array}$ \\
\hline 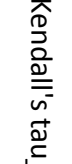 & $\begin{array}{l}\text { Birleşme Sonrası } \\
\text { Yeni Özdeşleşme }\end{array}$ & $\begin{array}{l}\text { Correlation } \\
\text { Coefficient } \\
\text { Sig. (2-tailed) }\end{array}$ & $\begin{array}{c}, 451^{* *} \\
0\end{array}$ & 1 & $\begin{array}{c}346^{* *} \\
0\end{array}$ \\
\hline & $\begin{array}{l}\text { İş } \\
\text { Doyumu }\end{array}$ & $\begin{array}{l}\text { Correlation } \\
\text { Coefficient } \\
\text { Sig. (2-tailed) }\end{array}$ & $\begin{array}{c}, 487^{* *} \\
0\end{array}$ & $\begin{array}{c}346^{* *} \\
0\end{array}$ & 1 \\
\hline
\end{tabular}

\begin{tabular}{|c|c|c|c|c|c|}
\hline N 143- & & & 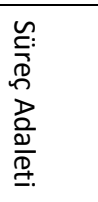 & $\begin{array}{c}\text { Birleşme } \\
\text { Sonrası } \\
\text { Yeni } \\
\text { Özdeşleş } \\
\text { me }\end{array}$ & 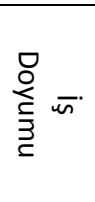 \\
\hline \multirow{3}{*}{ 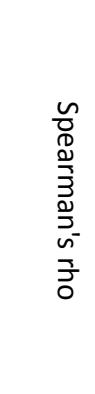 } & & Sig. (2-tailed) & 0 & 0 & 0 \\
\hline & Süreç Adaleti & $\begin{array}{l}\text { Correlation } \\
\text { Coefficient } \\
\text { Sig. (2-tailed) }\end{array}$ & 1 & $\begin{array}{c}, 587^{* *} \\
0\end{array}$ & $\begin{array}{c}, 601^{* *} \\
0\end{array}$ \\
\hline & $\begin{array}{l}\text { Birleşme } \\
\text { Sonrası Yeni } \\
\text { Kimlik }\end{array}$ & $\begin{array}{l}\text { Correlation } \\
\text { Coefficient } \\
\text { Sig. (2-tailed) }\end{array}$ & $\begin{array}{c}, 587^{* *} \\
0\end{array}$ & 1 & $\begin{array}{c}441^{* *} \\
0\end{array}$ \\
\hline
\end{tabular}




\begin{tabular}{|l|l|c|c|c|}
\hline $\begin{array}{l}\text { Iş̧ } \\
\text { Doyumu }\end{array}$ & $\begin{array}{l}\text { Correlation } \\
\text { Coefficient } \\
\text { Sig. (2-tailed) }\end{array}$ &, $601^{* *}$ &, $441^{* *}$ & 1 \\
\hline
\end{tabular}

Tablo'da verilen Spearman korelasyon analiz sonuçlarına göre, süreç adaleti, iş doyumu ve yeni özdeşleşme arasında anlamlı bir ilişki olduğu görülmektedir.

Araştırma Hipotezlerinin Regresyon Analizi (Bootstrap Yöntemi) Test Sonuçları:

Araştırma hipotezinin regresyon analizi bootstrap analiz yöntemi ile yapılmıştır.

"Yönetime duyulan güven, iletişim iklimi, süreç adaleti olumlu algısı ve kültür algısı, banka birleşmesi sonrası yeni kurumla özdeşleşmesi aracılığı ile çalışanın iş doyumunu olumlu etkilemektedir."

ana hipotezi ve alt hipotezlerin testi için bootstrap regresyon analizi tekniği kullanılmıştır.

Bootstrap analizi, 1000 örneklem ve yüzde 95 güven aralığı içinde yapılmıştır. Bootstrap istatistik test sonuçları değişkenler bazında ayrı ayrı aşağıda detaylı olarak verilmektedir.

Araştırmamızda aracılık etkisinin istatistiksel olarak anlamlıı̆̆ bootstrap metodu kullanılarak ölçülmüştür ${ }^{49}$. Standardize olmayan aracılık etkisi, her bir 1.000 bootstrap örneği için hesaplanmıştır ${ }^{50}$ ve \%95'lik güven aralı̆̆ı $2.5^{\prime}$ ncu ve $97.5^{\prime}$ ncu persentlerdeki aracilık etkileri saptanarak hesaplanmıştır.

\section{Süreç Adaletinin, Çalışanın Banka Birleşmesi Sonrası Yeni Kurumla Özdeşleşmesi Aracılığıyla İş Doyumuna Etkileri}

Süreç adaleti olumlu algısı, banka birleşmesi sonrası yeni kurumla özdeşleşmesi aracılığıyla, çalışanın, iş doyumunu olumlu etkilemektedir. Süreç adaleti alt hipotezi testi ile ilgili olarak bootstrap regresyon analiz sonuçları, model ve tabloları aşağıda verilmektedir.

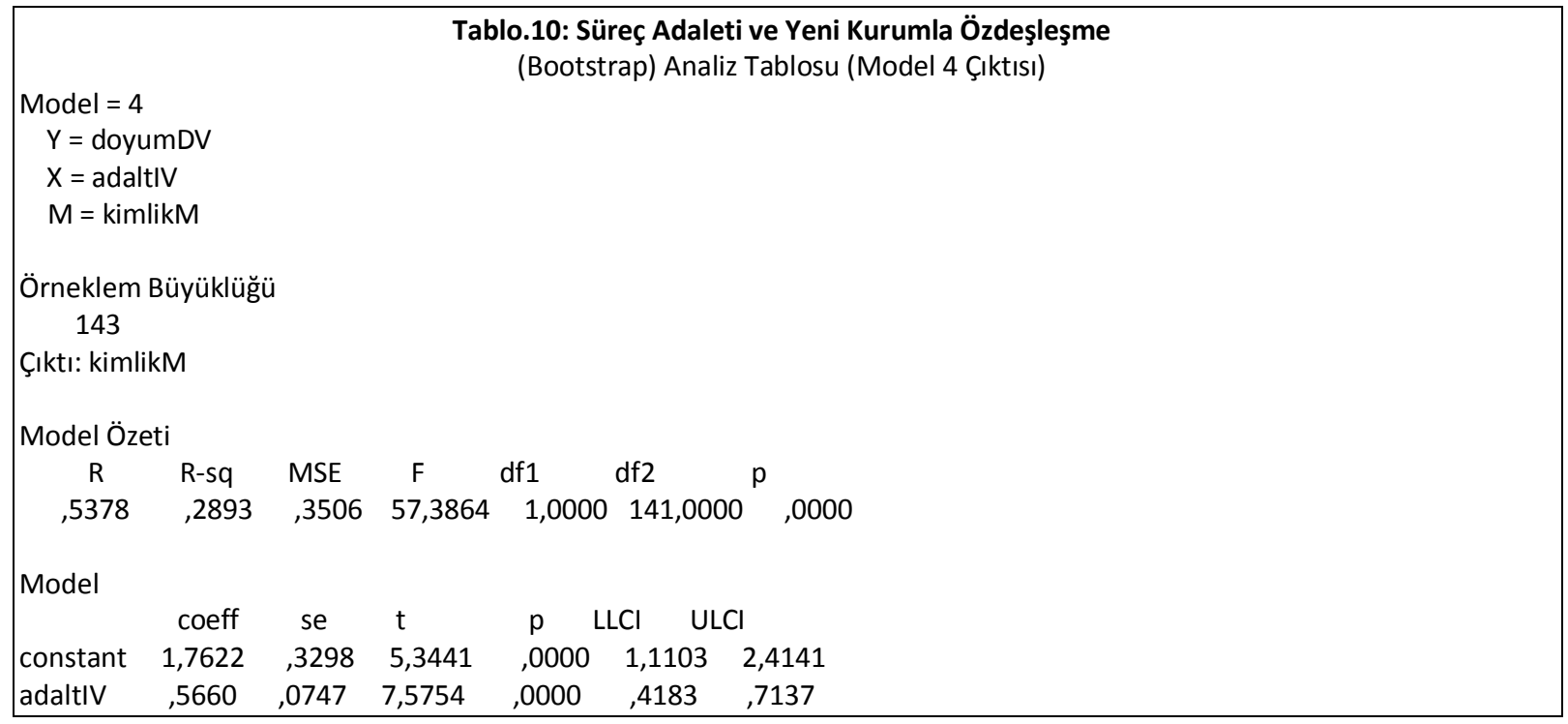

Tablo 10/Model 4 tablosu, banka birleşmesi sonrası yeni kurumla özdeşleşme ile süreç adaleti arasındaki basit regresyon sonuçlarını göstermektedir. Banka birleşmesi sonrası yeni kurumla özdeşleşme ve süreç adaleti olumlu algısı arasında anlamlı bir ilişki vardır

(b:0.56, t:7.58, p:.00). $b$ değerinin pozitif olması ilişkinin de pozitif yönlü yani süreç adaleti olumlu algısı arttıkça, çalışanın yeni kurumla özdeşleşmesinin de arttığını göstermektedir. $R 2$ değeri, süreç adaleti olumlu algısının, yeni kurumla özdeşleşme ilişkisindeki değişikliğin yüzde 29 'sini açıkladığını göstermektedir. 
Tablo.11: Süreç Adaleti Algısı ve Yeni Kurumla Özdeşleşmenin İş Doyumuna Etkisi (Bootstrap) Analiz Tablosu

\begin{tabular}{|c|c|c|c|c|c|c|}
\hline \multicolumn{4}{|c|}{ 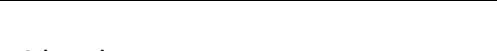 } & \multirow{2}{*}{\multicolumn{3}{|c|}{ (Çıktı: İş Doyumu Bağ }} \\
\hline Çıktı: doy & $\mathrm{mDV}$ & & & & & \\
\hline \multicolumn{7}{|c|}{ Model Özeti } \\
\hline $\mathrm{R}$ & R-sq & MSE & $\mathrm{F}$ & df1 & $\mathrm{df} 2$ & $\mathrm{p}$ \\
\hline ,6514 & ,4243 & 2354 & 51,5839 & 2,0000 & 140,0000 & $0 \quad, 000$ \\
\hline \multicolumn{7}{|l|}{ Model } \\
\hline & coeff & se & $\mathrm{t}$ & $\mathrm{p}$ & $\mathrm{LLCl}$ & $\mathrm{LCl}$ \\
\hline constant & 1,6379 & 2963 & 5,5277 & ,0000 & 1,0521 & 2,2238 \\
\hline kimlikM & 0972 & ,0690 & 1,4089 & 1611 &,- 0392 & ,2337 \\
\hline adaltlV & ,5608 & ,0726 & 7,7225 & ,0000 & ,4172 & 7044 \\
\hline
\end{tabular}

Yukardaki tablo, süreç adaleti olumlu algısı ve banka birleşmesi sonrası yeni kurumla özdeşleşmenin her ikisinin birlikte, çalışanın iş doyumu üzerindeki regresyon sonuçlarını göstermektedir.

İş doyumu üzerindeki hem süreç adaleti, hem de banka birleşmesi sonrası yeni kurumla özdeşleşmesinin çalışanın iş doyumu üzerindeki etkilerini göstermektedir. Model süreç adaletinin, çalışanın iş doyumu üzerinde, banka birleşmesi sonrası yeni kurumla özdeşleşme ile ilişki halinde etkisinin anlamlı olmadığını göstermektedir (p:0.16) güven aralığı ( -,0392 ve ,2337) SIFIR değerini kapsamaktadır.

\begin{tabular}{|c|c|c|c|c|c|c|}
\hline & & & Tablo.1 & $\begin{array}{l}\text { Süreç A } \\
\text { Topla }\end{array}$ & $\begin{array}{l}\text { daletinin } \\
\text { m Etki (Bo }\end{array}$ & $\begin{array}{l}\text { (Tek Başına) İş Doyumu Üzerindeki } \\
\text { otstrap) Analiz Tablosu }\end{array}$ \\
\hline Çıktı: doy & $\mathrm{mDV}$ & & & & & \\
\hline Model Öz & & & & & & \\
\hline $\mathrm{R}$ & R-sq & MSE & $\mathrm{F}$ & df1 & $\mathrm{df} 2$ & $p$ \\
\hline 6451 & ,4161 & 2371 & 100,4810 & 1,0000 & 141,0000 & ,0000 \\
\hline Model & & & & & & \\
\hline & coeff & se & $\mathrm{t}$ & $\mathrm{p} \quad \mathrm{L}$ & $\mathrm{LCl} \quad$ ULC & \\
\hline constant & 1,8093 & ,2712 & 6,6725 & ,0000 & 1,2732 & 2,3453 \\
\hline adaltIV & 6158 & 0614 & 10,0240 & ,0000 & ,4944 & 7373 \\
\hline
\end{tabular}

Toplam etki tablosu, süreç adaleti olumlu algısının, iş doyumu üzerindeki toplam etkisini göstermektedir. Toplam etki modelinde, aracı değişken banka birleşmesi sonrası yeni kurumla özdeşleşme olmaksızın, süreç adaletinin tek başına iş doyumuna etkisini göstermektedir. Süreç adaletinin, tek başına (banka birleşmesi sonrası yeni kurumla özdeşleşme olmaksızın), iş doyumunu anlamlı olarak etkilediğini göstermektedir $(b: 0.62, \quad \mathrm{t}: 10.02, \quad \mathrm{p}: 0,00) . \quad b \quad$ değerinin pozitif olması, ilişkinin pozitif yönlü olduğunu göstermektedir.

$R 2$ değeri, süreç adaletinin, iş doyumundaki değişikliğin yüzde $41^{\prime}$ ini açıkladığını göstermektedir.

\section{ARAŞTIRMA SONUÇLARININ DEĞERLENDIRILMESi}

İşletme birleşmeleri kapsamında, bankacılık sektöründe banka birleşmeleri üzerine yapılan bu örnek olay inceleme kapsamındaki, 25.Ocak.2011'de, Fortis ve TEB bankalarının birleşme öncesi TEB 335 şube ve 5,646 olan çalışan sayısı, Fortis ile birleşmeyi takip eden 2011 yılı sonunda şube sayısı 507'e, çalışan sayısı ise 9.356'ya yükselmiştir (TEB Faaliyet Raporu, $2011)^{51}$.

“Birleşik Banka” faaliyetlerini, (2013 sonu verilerine göre) 544 şube ve 10 bin personel ile sürdürmektedir. 
Çalışanın, banka birleşmesi sonrası yeni birleşik banka ile özdeşleşmesi, süreç adaleti olumlu algısı ile çalışanların iş doyumu üzerindeki etkileri bir örnek olay incelemesi ile araştırılmıştır. Ayrıca çalışanın yeni kurum ile özdeşleşmesinin, iş doyumu ile söz konusu unsurlar arasındaki aracılık etkisi de incelenmiştir.

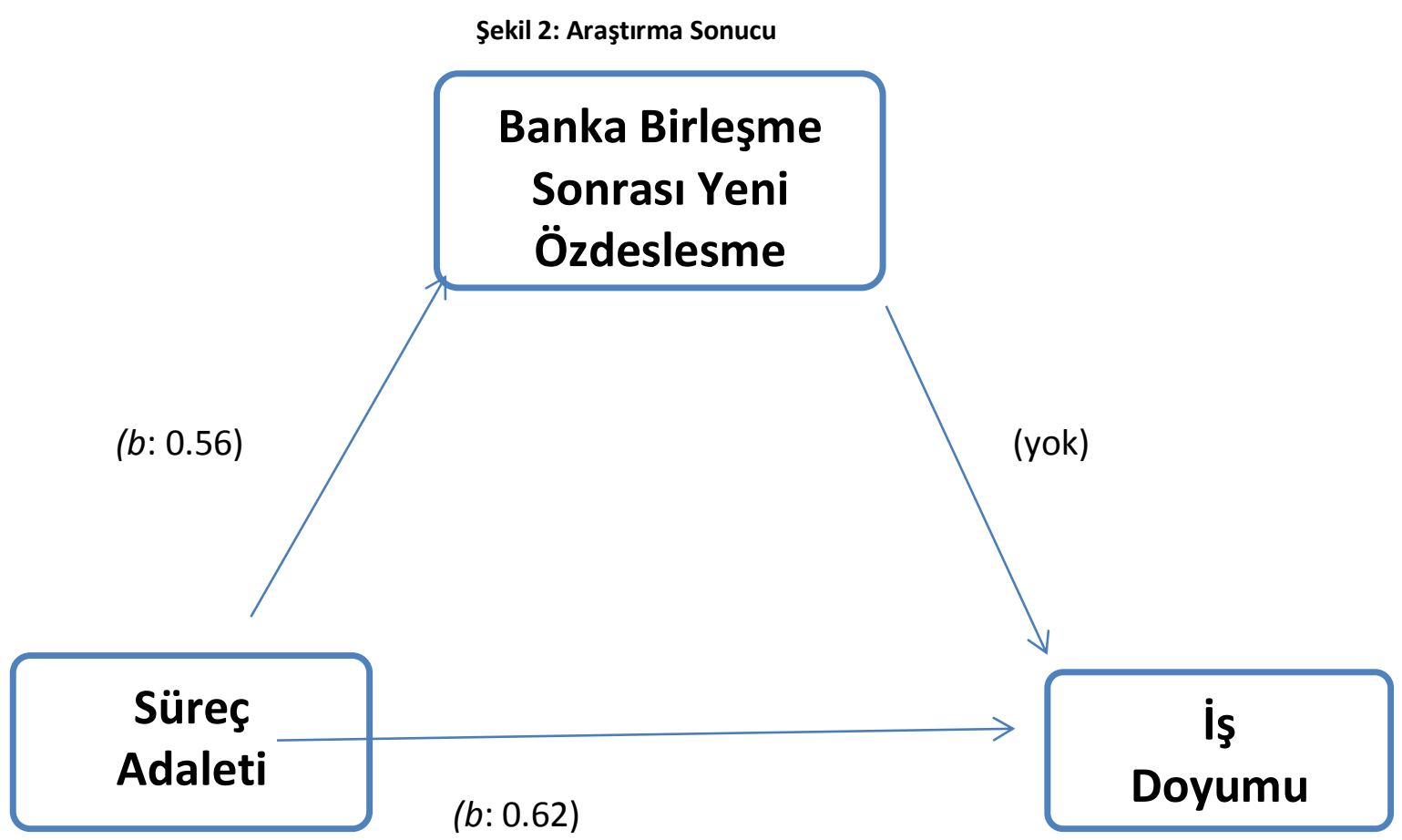

Araştırma hipotez ve alt hipotezlerinin testi için bootstrap regresyon analizi tekniği kullanılmıştır. Banka birleşmesi sonrası yeni kurumla özdeşleşme aracılık etkilerinin ölçümünde 1000 örneklem ve yüzde 95 güven aralığı bootsktrap analiz ${ }^{52}$ testi sonucu: Bağımsız değişken, süreç adaleti olumlu algısı, bağımlı değişken iş doyumu üzerindeki etkisinde, aracı değişken yeni kurumla özdeşleşmesinin, aracılık rolü ${ }^{53}$ incelenmiş, bootstrap yöntemi ile yapılan bootstrap regresyon analiz sonuçlarında, banka birleşmesi sonrası yeni kurumla özdeşleşmenin süreç adaleti ve iş doyumu arasındaki aracılık etkisinin, güven aralığı (Cl: -,0089 ,1510) SIFIR değerini içerdiğinden (negatif değerler arası) anlamlı olmadığını göstermektedir. Yani

- "Süreç adaleti olumlu algısı, banka birleşmesi sonrası yeni kurumla özdeşleşmesi aracılığıyla, çalışanın iş doyumunu olumlu etkilemektedir."

hipotezi doğrulanmamıştır.

Süreç Adaleti ve İş Doyumu iliş̧isi

- Süreç adaleti iş doyumunu olumlu etkiler alt hipotezi doğrulanmıştır.

Süreç Adaleti ve Yeni Özdeşleşme (Banka Birleşme Sonrası) ilişkisi

- Süreç adaleti olumlu algısı ve banka birleşmesi sonrası yeni kurumla özdeşleşme arasında anlamlı bir ilişki vardır

(b:0.56, t:7.58, p:.00).

$b$ değerinin pozitif olması ilişkinin de pozitif yönlü yani süreç adaleti olumlu algısı arttıkça, iş doyumunun da arttığını göstermektedir.

$R 2$ değeri, süreç adaletinin, yeni kurumla özdeşleşme ilişkisindeki değişikliğin yüzde 29'sini açıkladığını göstermektedir. 
- Süreç adaleti olumlu algısı tek başına (banka birleşmesi sonrası yeni kurumla özdeşleşme olmadığında) iş doyumunu anlamlı olarak etkilemektedir.

(b: 0.62, $\mathrm{t}:$ :10.02, $\mathrm{p}: 0,00)$.

$R 2$ değeri, süreç adaletinin, iş doyumundaki değişikliğin yüzde 4'ini açıkladığını göstermektedir.

$b$ değerinin pozitif olması, ilişkinin pozitif yönlü olduğunu göstermektedir.

- $\quad$ Süreç adaleti yeni özdeşleşmeyi olumlu etkiler.

alt hipotezi doğrulanmıştır.

\section{ARAŞTIRMA SONUÇLARI VE TARTIŞMA}

İşletme birleşmelerinde başarısızlık nedenlerinden birisi çalışanların memnuniyetlerine odaklanılmaması olarak belirlenmiştir. Bu nedenle, işletme birleşmelerinin başarısı için yöneticilerin odaklanması gereken çalışanın memnuniyetini etkileyen unsurlardan süreç adaleti ve banka birleşme sonrası yeni özdeşleşme unsurları araştırma sonucu,

- $\quad$ süreç adaletinin, çalışanın iş doyumunu olumlu etkilediği ve

- $\quad$ süreç adaletinin, çalışanın yeni kurumla özdeşleşmesini olumlu etkilediği

göstermektedir.

Bu sonuç literatür ile uyumludur.

İşletme birleşmelerinde süreç adaleti olumlu algısı, çalışanın kurumla özdeşleşmesini ve iş doyumunu olumlu etkilemektedir ${ }^{54}$.

Süreç adaleti olumlu algısının çalışanın yeni kurumla özdeşleşmesini olumlu etkilediği tespit edilmiştir ${ }^{55}$.

Ancak yeni kurumla özdeşleşmenin, süreç adaleti ve iş doyumu arasındaki ilişkide, dolaylı etkisine (aracılık) bakıldığında bu etki bulunmamış olup bunun katılımcıların (banka birleşmesi öncesi iki bankanın) eşit şekilde temsil edilmediğinden kaynaklandığı düşünülmektedir.

Araştırmamızda, yaş gruplarına göre anlamlı bir farklılık olduğu görülmektedir. Süreç adaleti olumlu algısı 31 ile 40 yaş aralığındaki katılımcılarda daha yüksek olduğu görülmüştür. Bu gençlerin, yaşlılara göre adaletsizliğe daha duyarlı olduğunu gösteren (Wagner, Rush, 2000) araştırma sonucu ile uyumludur.

Bu çalışmanın da diğer araştırmalarda olduğu gibi kıııtlııkları vardır, araştırmanın kapsamını; eski Fortis ve TEB bankaları birleşmesi sonucu yeni 'Birleşik Banka' çalışanları oluşturmaktadır. Bu nedenle araştırma sonuçları ile ilgili bu kapsamın dışında değerlendirme ve genellemeler yapılamamaktadır.

Literatürde, işletme birleşmeleri ile ilgili sınırlılığı oluşturan özellikle işletme birleşme öncesi ve sonrasını birlikte kapsayan çalışanlara yönelik yayınlar çok nadirdir, nitekim bu çalışma da TEB ve Fortis bankaları birleşmesi sonrası yapılmıştır.

Ayrıca özellikle bankacılık sektöründe, bilgi paylaşımı diğer sektörlere göre, yasa ile sınırlandırıldığından katıımcıları rahatlatmak için anket formu kapak yazısında gerekli izinlerin alındığı ve cevaplarının hiç bir şekilde kimse ile kullanılmayacağı ve sadece bilimsel araştırma için olduğu özellikle belirtilmiştir.

Banka birleşmesi sonrası geçen sürede, çalışanlardan, olaylar ve (işletme birleşme öncesi süreci de kapsayan) bilgiler nedeniyle, olumlu hatıralar veya zayıf hatırlanan olaylar nedeniyle cevapların etkilenmiş olabileceği kısıtılı̆ı̆ı olmakla birlikte araştırmanın banka birleşmesi sonrası birkaç yıl içinde olması kaydıyla doğruluk veya önyargı problemiyle karşılaşılmamaktadır ${ }^{56}$. İşletme birleşmeleri ile ilgili yapılan araştırmalarda, işletme birleşmesi sonrası çalışanların, yeni birleşik örgüt etkilerine alışmasının yıllar aldığı tespit edilmiştir ${ }^{57}$.

Araştırmamızın, işletme birleşmeleri ile ilgili çalışmalarda kaynak olacağı ve bunun yanı sıra ilerde yapılacak çalışmalarda hem işletme birleşmesi öncesi, hem de işletme birleşme sonrası daha geniş katılımla yapılacak çalışmaların yararlı olacağı düşünülmektedir. 
Bu çalışmada, banka birleşmelerinde, çalışanın özdeşleşmesini etkileyen unsur olarak süreç adaleti algısı incelenmiştir. Çalışanın, süreç adaleti olumlu algısının, yeni banka ile özdeşleşmesine etkisi araştırılmıştır. Ayrıca süreç adaleti olumlu algısı ve yeni banka ile özdeşleşmesinin, çalışanın iş doyumunu üzerindeki etkisi araştırılmıştır.

Çalışanın yeni birleşik banka ile özdeşleşmesinin, iş doyumu üzerindeki etkisi; süreç adaleti ile yeni birleşik banka ile özdeşleşmesi ve iş doyumu arasındaki ilişkilerin araştırılarak açıklanması hedeflenmiştir. Özellikle işletme birleşmelerinin başarısında önemli bir faktör olan, işletme birleşmesi sonrası yeni kurum ile özdeşleşme değişkeni aracı değişken olarak modele eklenmiştir.

İşletme birleşmelerinde, çalışanın iş doyumunu etkileyen, banka birleşmesi sonrası yeni kurum ile özdeşleşmesi ve özdeşleşmesini etkileyen unsurların incelenmesi ve sonuçlarının literatüre katkıda bulunacağı düşünülmektedir.

İlerde sadece, işletme birleşmesi sonrası değil, öncesini de kapsayan, banka birleşmeleri ile ilgili değil diğer sektörlerdeki işletme birleşmeleri ile çalışanların iş doyumunu ve banka birleşmesi sonrası yeni kurumla özdeşleşmesini etkileyen farklı faktörlerin araştırılması, farklı yönleri ortaya koyacaktır.

\section{SONUÇ}

Araştırma sonucunda,

Çalışanın adalet olumlu algısı ile iş doyumu arasında anlamlı ve pozitif bir ilişki tespit edilmiştir.

Çalışanın adalet olumlu algısı ile banka birleşmesi sonrası yeni kurumla özdeşleşmesi arasında anlamlı bir ilişki tespit edilmiştir.

Ancak banka birleşmesi sonrası yeni özdeşleşme ve iş doyumu arasında anlamlı bir ilişki olmayıp, yeni özdeşleşmenin, adalet olumlu a

TEB-Fortis bankaları (örnek olay) birleşmesinde, süreç adaleti olumlu algısının çalışanların iş doyumunu olumlu etkilediği gösterilmiştir.

Çalışma sonucu, yöneticilerin banka birleşmelerinin başarısı için çalışan memnuniyetinin önemini ve etkileyen faktörlerin bilimsel olarak ele alınması gerektiğini göstermektedir. 


\section{KAYNAKLAR}

Altunışık, Remzi, et al. Sosyal bilimlerde araştırma yöntemleri: SPSS uygulamalı. Sakarya Yayıncılık, 2010.

Ambrose, Maureen L., and Marshall Schminke. "The role of overall justice judgments in organizational justice research: a test of mediation." Journal of Applied Psychology 94.2 (2009): 491.

Ambrose, Maureen, Ronald L. Hess, and Shankar Ganesan. "The relationship between justice and attitudes: An examination of justice effects on event and system-related attitudes." Organizational Behavior and Human Decision Processes 103.1 (2007): 21-36.

Ashforth, Blake. Role transitions in organizational life: An identity-based perspective. Routledge, 2000.

Babbie, Earl. The practice of social research. Cengage Learning, 2012.

Beugre, Constant D., and Robert A. Baron. "Perceptions of systemic justice: The effects of distributive, procedural, and interactional justice." Journal of Applied Social Psychology 31.2 (2001): 324-339.

Büyüköztürk, Şener. "Faktör analizi: Temel kavramlar ve ölçek geliştirmede kullanımı." Kuram ve Uygulamada Eğitim Yönetimi Dergisi 8.4 (2002): 470-483.

Carmines, Edward G., and Richard A. Zeller, eds. Reliability and validity assessment. Vol. 17. Sage, 1979.

Cartwright, Sue, and Cary L. Cooper. "Organizational marriage:"hard” versus "soft” issues?." Personnel Review 24.3 (1995): $32-42$

Cropanzano, Russell, and Maureen L. Ambrose. "Procedural and distributive justice are more similar than you think: A monistic perspective and a research agenda." Advances in organizational justice 119 (2001): 151.

Dick, Rolf, Johannes Ullrich, and Patrick A. Tissington. "Working under a black cloud: How to sustain organizational identification after a merger." British Journal of management 17.S1 (2006): S69-S79.

Donovan, Michelle A., Fritz Drasgow, and Liberty J. Munson. "The Perceptions of Fair Interpersonal Treatment Scale: development and validation of a measure of interpersonal treatment in the workplace." Journal of Applied Psychology 83.5 (1998): 683.

Dutton, Jane E., Janet M. Dukerich, and Celia V. Harquail. "Organizational images and member identification." Administrative science quarterly (1994): 239-263.

Field, Andy. Discovering statistics using SPSS. Sage publications, 2009.

Folger, Robert, and Mary A. Konovsky. "Effects of procedural and distributive justice on reactions to pay raise decisions." Academy of Management journal 32.1 (1989): 115-130

Gaertner, S. L., B. A. Bachman, J. Dovidio and B. S. Banker (2001). 'Corporate mergers and stepfamily marriages: Identity, harmony, and commitment'. In: M. A. Hogg and D. J. Terry (eds), Social identity processes in organizational contexts, pp 265-282. Psychology Press, Philadelphia.

Greenberg, Jerald, and Robert A. Baron. "Behavior in organizations." (2011)

Greenberg, Jerald. "Organizational justice: Yesterday, today, and tomorrow." Journal of management 16.2 (1990): $399-432$

Gutek, Barbara A. "On the accuracy of retrospective attitudinal data." Public Opinion Quarterly 42.3 (1978): $390-401$.

Hackman, J. Richard, and Greg R. Oldham. Work redesign. (1980).

Hair, Joseph F., et al. Multivariate data analysis. Vol. 6. Upper Saddle River, NJ: Pearson Prentice Hall, 2006

Halvorsen, K. "Mergers creating inequalities." Journal for Contemporary Research 25 (1984): 389-414.

Hayes, A.F. http://www.afhayes.com/spss-sas-and-mplus-macros-and-code.html (çevrimiçi) 10.05.2015.

Hayes, Andrew F. Introduction to mediation, moderation, and conditional process analysis: A regression-based approach. Guilford Press, 2013.

Hogg, Michael A., and Barbara-A. Mullin. Joining groups to reduce uncertainty: Subjective uncertainty reduction and group identification. (1999).

Hoy, Wayne K., and C. John Tarter. "Organizational justice in schools: no justice without trust." International Journal of Educational Management 18.4 (2004): 250-259.

http://www.teb.com.tr/Document/vi/presentation/TEB\%202011\%201Q\%20BRSA\%20consoTR.pdf, (çevrimiçi) 24.12 .2014$.

Kalaycı, Şeref. SPSS uygulamalı çok değişkenli istatistik uygulamaları. (2009). 
Konovsky, Mary A. "Understanding procedural justice and its impact on business organizations." Journal of management 26.3 (2000): 489 511.

Leventhal, Gerald S. What should be done with equity theory?. Springer US, 1980.

Likert, Rensis. "A method of constructing an attitude scale." Scaling: a sourcebook for behavioral scientists. Chicago: Aldine (1974): 233243.

Mael, Fred, and Blake E. Ashforth. "Alumni and their alma mater: A partial test of the reformulated model of organizational identification." Journal of organizational Behavior 13.2 (1992): 103-123.

Marks, Mitchell Lee, and Philip H. Mirvis. "Rebuilding after the merger: Dealing with "survivor sickness"." Organizational dynamics 21.2 (1992): 18-32.

Moorman, Robert H. "Relationship between organizational justice and organizational citizenship behaviors: do fairness perceptions influence employee citizenship?." Journal of applied psychology 76.6 (1991): 845.

O'Reilly, Charles A., and Jennifer Chatman. "Organizational commitment and psychological attachment: The effects of compliance, identification, and internalization on prosocial behavior." Journal of applied psychology 71.3 (1986): 492.

Preacher, Kristopher J., and Andrew F. Hayes. "Asymptotic and resampling strategies for assessing and comparing indirect effects in multiple mediator models." Behavior research methods 40.3 (2008): 879-891.

Price, J. L., and C. W. Mueller. Handbook of organizational measurement, 1986. Pitman, Marshfield, MA.

Punch, Keith F. Introduction to social research: Quantitative and qualitative approaches. Sage, 2013.

Rhoades, L. and R. Eisenberger (2002). 'Perceived organizational support: A review of the literature', Journal of Applied Psychology, 87, pp. 698-714.

Sekreter, Seyhan, and Gökhan Akyüz. "Pazarlama Araştırmalarında Kullanılan Ölçeklere ilişskin Bir Yayın Taraması." Akdeniz Üniversitesi, IiiBF Dergisi 6: 123-150.

Shrout, Patrick E., and Niall Bolger. "Mediation in experimental and nonexperimental studies: new procedures and recommendations." Psychological methods 7.4 (2002): 422.

Sipahi, Beril, E. Serra Yurtkoru, and Murat Çinko. Sosyal bilimlerde SPSS'le veri analizi. Beta, 2008.

Smidts, Ale, Ad Th H. Pruyn, and Cees BM Van Riel. "The impact of employee communication and perceived external prestige on organizational identification." Academy of management journal 44.5 (2001): 1051-1062.

TEB, 2011 ilk Çeyrek Bilgilendirme, (çevrimiçi)

Toprak, 2006: 57

Turgut, M. Fuat, and Yaşar Baykul. Ölçekleme teknikleri. Ankara: ÖSYM yayınları 1 (1992).

Ullrich, Johannes, Jan Wieseke, and Rolf Van Dick. "Continuity and Change in Mergers and Acquisitions: A Social Identity Case Study of a German Industrial Merger." Journal of Management Studies 42.8 (2005): 1549-1569.

Van Dick, Rolf, Johannes Ullrich, and Patrick A. Tissington. "Working Under a Black Cloud: How to Sustain Organizational Iden tification after a Merger." British Journal of management 17.S1 (2006): S69-S79.

Van Knippenberg, Daan, and Naomi Ellemers. "Social Identity and Group Performance." Social identity at work: Developing theory for organizational practice (2003): 29.

Van Knippenberg, Daan, et al. "Organizational identification after a merger: A social identity perspective." British Journal of Social Psychology 41.2 (2002): 233-252.

Viswesvaran, Chockalingam, and Deniz S. Ones. "Examining the construct of organizational justice: A meta-analytic evaluation of relations with work attitudes and behaviors." Journal of Business Ethics 38.3 (2002): 193-203.

Wagner, Sharon L., and Michael C. Rush. "Altruistic organizational citizenship behavior: Context, disposition, and age." The Journal of Social Psychology 140.3 (2000): 379-391.

Werhane, Patricia H. "Two ethical issues in mergers and acquisitions." Journal of business ethics 7.1-2 (1988): 41-45

Yürür, Senay. "Örgütsel adalet ile iş tatmini ve çalışanların bireysel özellikleri arasındaki ilişkilerin analizine yönelik bir araştırma." Süleyman Demirel Üniversitesi îktisadi ve İdari Bilimler Fakültesi Dergisi 13.2 (2008): 295-312.

Zapata-Phelan, Cindy P., et al. "Procedural justice, interactional justice, and task 


\section{REFERANS}

${ }^{1}$ Colquitt, Jason A., et al. "Justice at the millennium: a meta-analytic review of 25 years of organizational justice research." Journal of applied psychology 86.3 (2001): 425.

2 Konovsky, Mary A. "Understanding procedural justice and its impact on business organizations." Journal of management 26.3 (2000): 489-511.

${ }^{3}$ Beugre, Constant D., and Robert A. Baron. "Perceptions of systemic justice: The effects of distributive, procedural, and interactional justice." Journal of Applied Social Psychology 31.2 (2001): 324-339.

${ }^{4}$ Tang, Thomas Li-Ping, and Linda J. Sarsfield-Baldwin. Distributive and Procedural Justice as Related to Satisfaction and Commitment. (1996).

${ }_{5}^{5}$ Smidts, Ale, Ad Th H. Pruyn, and Cees BM Van Riel. "The impact of employee communication and perceived external prestige on organizational identification." Academy of management journal 44.5 (2001): 1051-1062.

${ }^{6}$ Viswesvaran, Chockalingam, and Deniz S. Ones. "Examining the construct of organizational justice: A meta-analytic evaluation of relations with work attitudes and behaviors." Journal of Business Ethics 38.3 (2002): 193-203.

7 Cropanzano, Russell, and Maureen L. Ambrose. "Procedural and distributive justice are more similar than you think: A monistic perspective and a research agenda." Advances in organizational justice 119 (2001): 151.

${ }^{8}$ Leventhal, Gerald S. What should be done with equity theory?. Springer US, 1980.

Likert, Rensis. "A method of constructing an attitude scale." Scaling: a sourcebook for behavioral scientists. Chicago: Aldine (1974): 233243.

${ }_{9}$ Folger, Robert, and Mary A. Konovsky. "Effects of procedural and distributive justice on reactions to pay raise decisions." Academy of Management journal 32.1 (1989): 115-130

${ }^{10}$ Werhane, Patricia H. "Two ethical issues in mergers and acquisitions." Journal of business ethics 7.1-2 (1988): $41-45$

${ }^{11}$ Halvorsen, K. "Mergers creating inequalities." Journal for Contemporary Research 25 (1984): 389-414.

${ }^{12}$ Dick, Rolf, Johannes Ullrich, and Patrick A. Tissington. "Working under a black cloud: How to sustain organizational identification after a merger." British Journal of management 17.S1 (2006): S69-S79.

${ }^{13}$ Van Knippenberg, Daan, et al. "Organizational identification after a merger: A social identity perspective." British Journal of Social Psychology 41.2 (2002): 233-252.

${ }^{14}$ Van Dick, Rolf, Johannes Ullrich, and Patrick A. Tissington. "Working Under a Black Cloud: How to Sustain Organizational Identification after a Merger." British Journal of management 17.S1 (2006): S69-S79.

${ }^{15} \mathrm{Hogg}$, Michael A., and Barbara-A. Mullin. "Joining groups to reduce uncertainty: Subjective uncertainty reduction and group identification." (1999).

${ }^{16}$ Mael, Fred, and Blake E. Ashforth. "Alumni and their alma mater: A partial test of the reformulated model of organizational identification." Journal of organizational Behavior 13.2 (1992): 103-123.

${ }^{17}$ Van Knippenberg, Daan, et al. "Organizational identification after a merger: A social identity perspective." British Journal of Social Psychology 41.2 (2002): 233-252.

${ }_{18}$ Parsons, Elizabeth, and Adelina Broadbridge. "Job motivation and satisfaction: Unpacking the key factors for charity shop managers." Journal of Retailing and Consumer Services 13.2 (2006): 121-131.

${ }^{19}$ Putti, Joseph M., Samuel Aryee, and Joseph Phua. "Communication relationship satisfaction and organizational commitment." Group and Organization Management 15.1 (1990): 44-52.

${ }^{20}$ Ilozor, Doreen B., Ben D. llozor, and John Carr. "Management communication strategies determine job satisfaction in telecommuting." Journal of management development 20.6 (2001): 495-507.

${ }^{21}$ Greenberg, Jerald. "A taxonomy of organizational justice theories." Academy of Management review 12.1 (1987): 9-22.

${ }^{22}$ Sweeney, Paul D., and Dean B. McFarlin. "Workers' Evaluations of the" Ends" and the" Means": An Examination of Four Models of Distributive and Procedural Justice." Organizational behavior and human decision processes 55.1 (1993): 23-40

${ }^{23}$ Aryee, Samuel, Pawan S. Budhwar, and Zhen Xiong Chen. "Trust as a mediator of the relationship between organizational justice and work outcomes: Test of a social exchange model." Journal of organizational Behavior 23.3 (2002): 267-285.

${ }^{24}$ Colquitt, Jason A., et al. "Justice at the millennium: a meta-analytic review of 25 years of organizational justice research." Journal of applied psychology 86.3 (2001): 425.

${ }^{25}$ Babbie, Earl. The practice of social research. Cengage Learning, 2012.

${ }^{26}$ Hackman, J. Richard, and Greg R. Oldham. Work redesign. (1980).

${ }^{27}$ Van Knippenberg, Daan, et al. "Organizational identification after a merger: A social identity perspective." British Journal of Social Psychology 41.2 (2002): 233-252.

${ }^{28}$ Moorman, Robert H. "Relationship between organizational justice and organizational citizenship behaviors: do fairness perceptions influence employee citizenship?." Journal of applied psychology 76.6 (1991): 845.

${ }^{29}$ Moorman, Robert H. "Relationship between organizational justice and organizational citizenship behaviors: do fairness perceptions influence employee citizenship?." Journal of applied psychology 76.6 (1991): 845.

${ }^{30}$ Greenberg, Jerald. "Organizational justice: Yesterday, today, and tomorrow." Journal of management 16.2 (1990): 399-432

${ }^{31}$ Price, J. L., and C. W. Mueller. Handbook of organizational measurement, 1986. Pitman, Marshfield, MA.

${ }^{32}$ Greenberg, Jerald, and Robert A. Baron. "Behavior in organizations." (2011). 


\footnotetext{
${ }^{33}$ Donovan, Michelle A., Fritz Drasgow, and Liberty J. Munson. "The Perceptions of Fair Interpersonal Treatment Scale: development and validation of a measure of interpersonal treatment in the workplace." Journal of Applied Psychology 83.5 (1998): 683.

${ }^{34}$ Folger, Robert, and Mary A. Konovsky. "Effects of procedural and distributive justice on reactions to pay raise decisions." Academy of Management journal 32.1 (1989): 115-130

${ }^{35}$ Hoy, Wayne K., and C. John Tarter. "Organizational justice in schools: no justice without trust." International Journal of Educational Management 18.4 (2004): 250-259.

${ }^{36}$ Ambrose, Maureen L., and Marshall Schminke. "The role of overall justice judgments in organizational justice research: a test of mediation." Journal of Applied Psychology 94.2 (2009): 491.

${ }^{37}$ Altunışık, Remzi, et al. Sosyal bilimlerde araştırma yöntemleri: SPSS uygulamalı. Sakarya Yayıncılık, 2010.

${ }^{38}$ Punch, Keith F. Introduction to social research: Quantitative and qualitative approaches. Sage, 2013.

${ }^{39}$ Carmines, Edward G., and Richard A. Zeller, eds. Reliability and validity assessment. Vol. 17. Sage, 1979.

${ }^{40}$ Büyüköztürk, Şener. "Faktör analizi: Temel kavramlar ve ölçek geliştirmede kullanımı." Kuram ve Uygulamada Eğitim Yönetimi Dergisi 8.4 (2002): 470-483.

${ }^{41}$ Toprak, 2006: 57

${ }^{42}$ Sipahi, Beril, E. Serra Yurtkoru, and Murat Çinko. Sosyal bilimlerde SPSS'le veri analizi. Beta, 2008.

${ }^{43}$ Sipahi, Beril, E. Serra Yurtkoru, and Murat Çinko. Sosyal bilimlerde SPSS'le veri analizi. Beta, 2008.

${ }^{44}$ Hair, Joseph F., et al. Multivariate data analysis. Vol. 6. Upper Saddle River, NJ: Pearson Prentice Hall, 2006

${ }^{45}$ TEB, 2011 illk Çeyrek Bilgilendirme, (çevrimiçi)

http://www.teb.com.tr/Document/yi/presentation/TEB\%202011\%201Q\%20BRSA\%20consoTR.pdf 24.12.2014

${ }^{46}$ TEB, 2011 illk Çeyrek Bilgilendirme, (çevrimiçi)

http://www.teb.com.tr/Document/yi/presentation/TEB\%202011\%201Q\%20BRSA\%20consoTR.pdf 24.12.2014

${ }^{47}$ Andy P. Field, Discovering Statistics Using SPSS, London: Sage Publication, 2005, p.93,

${ }^{48}$ Andy Field, a.g.e.p. 93

${ }^{49}$ Hayes, Andrew F. Introduction to mediation, moderation, and conditional process analysis: A regression-based approach. Guilford Press, 2013.

${ }^{50}$ Hayes, A.F. http://www.afhayes.com/spss-sas-and-mplus-macros-and-code.html (çevrimiçi) 10.05.2015.

${ }^{51}$ TEB, 2011 ilk Çeyrek Bilgilendirme,

http://www.teb.com.tr/Document/yi/presentation/TEB\%202011\%201Q\%20BRSA\%20consoTR.pdf, (çevrimiçi) 24.12.2014.

${ }^{52}$ Preacher, Kristopher J., and Andrew F. Hayes. "Asymptotic and resampling strategies for assessing and comparing indirect effects in multiple mediator models." Behavior research methods 40.3 (2008): 879-891.

${ }^{53}$ Shrout, Patrick E., and Niall Bolger. "Mediation in experimental and nonexperimental studies: new procedures and recommendations." Psychological methods 7.4 (2002): 422.

${ }^{54}$ Smidts, Ale, Ad Th H. Pruyn, and Cees BM Van Riel. "The impact of employee communication and perceived external prestige on organizational identification." Academy of management journal 44.5 (2001): 1051-1062.

${ }^{55}$ Beugre, Constant D., and Robert A. Baron. "Perceptions of systemic justice: The effects of distributive, procedural, and interactional justice." Journal of Applied Social Psychology 31.2 (2001): 324-339.

${ }_{56}^{56}$ Gutek, Barbara A. "On the accuracy of retrospective attitudinal data." Public Opinion Quarterly 42.3 (1978): 390-401.

${ }^{57}$ Marks, Mitchell Lee, and Philip H. Mirvis. "Rebuilding after the merger: Dealing with "survivor sickness"." Organizational dynamics 21.2 (1992): 18-32.
} 